\title{
Utilization of Different Corn Fractions by Broilers
}

ISSN 1516-635X Jul - Sept 2015 / v.17 / n.3 / 307-312

http://dx.doi.org/10.1590/1516-635x1703307-312

\section{-Author(s)}

Costa SIFR

Stringhini JH"

Ribeiro AML"

Pontalti G'II

MacManus CIII

Post Graduate Course in Animal Sciences, University of Brasília, Brasilia, DF, Brazil

" Department of Animal Production, Veterinary School, Federal University of Goiás, Goiânia, Brazil

III Department of Animal Production, Federal University of Rio Grande do Sul, Porto Alegre, Brazil

\section{Mail Address}

Corresponding author e-mail address Sandra Costa

Rua Ettore Soliani, 471, Distrito Industrial Nova Era, Indaiatuba, SP, 13347-394 Phone/Fax: 55 (19) 21078002

E-mail: sandra.rodrigues@kemin.com

\section{-Keywords}

Corn quality, corn density, metabolizable energy, broilers

\section{ABSTRACT}

This study was conducted to evaluate the nutritional values of fractions of damaged corn. One hundred and eighty 22-d-old Cobb 500 male broilers were distributed in batteries according to a completely randomized design with six treatments of six replicates each. The treatments consisted of diets containing five corn fractions, classified as sound, fermented, insect-damaged, mold-damaged, or reference corn. The test diets consisted of $60 \%$ of reference diet + $40 \%$ of each corn fraction. Only the reference corn fraction included all the fractions at different proportions $(0.8 \%$ fermented, $0.05 \%$ insectdamaged, 3.3\% mold-damaged, and $95.85 \%$ sound grains). The method of total excreta collection was used to determine AMEn values and metabolizability coefficients of dry matter (MDM), crude protein $(\mathrm{MCP})$, ether extract (MEE), and gross energy (MGE) of the reference corn and its fractions. The density values of the corn fractions were used to calculate the correlations among the evaluated parameters. The evaluated corn fractions presented different compositions values. The insect-damaged and mold-damaged grains presented higher CP level, lower density, and MDM and MCP coefficients compared with the other fractions. However, calculated AMEn values were not significantly different ( $p>0.05)$ among corn fractions. A low correlation between density and AMEn content $(r<0.5)$, and a high correlation between density and MCP $(r>0.8)$ were calculated. Although the evaluated corn fractions presented different nutritional values, there were no marked differences in their utilization by broilers.

\section{INTRODUCTION}

Corn (Zea mays) is grown in almost all over the Brazilian territory, with an average of 80 million tonnes produced per year (Conab, 2015). Corn is grown in different ecosystems and under different climatic conditions, management systems, and soil types, which may alter its nutritional values (Galon et al., 2010).

Brazil has an official corn classification system defined by the Ministry of Agriculture (MAPA, 1976) in the White Paper n. 845 of November 8, 1976, and ammended by White Paper n. 11 of April 12, 1996 (MAPA, 1996) and White Paper n. 60 of $23^{\text {rd }}$ of December, 2011 (MAPA, 2011). This official system includes seven grain fractions: intact, molddamaged, broken, sprouted, insect-damaged, hollow, and broken. The feed industry often uses low-quality corn (Type 3), characterized by up to $3 \%$ foreign material, impurities and fragments; $27 \%$ broken grains; and a maximum of $10 \%$ mold-damaged and sprouted grains.

This classification is not useful because grains of the same type may have different chemical content, which affects their nutritional and energy values (Silva et al. 2008; Silva et al., 2011). There is little information 
on the influence of each fraction on the quality of a corn sample. According to Lopez et al. (1990), diets containing up to $50 \%$ insect-damaged corn did not negatively affect the productivity of growing and finishing pigs. Silva et al. (2008) found that low-density corns present high percentages of mold-damaged, broken, and hollow grains, as well as low metabolizable energy. On the other hand, Lesson et al. (1993) and Dale \& Jackson (1994) reported that corn density is not a sound predictor of its nutritional value.

The aim of this study was to evaluate the nutritional value of different fractions of corn (fermented, insectdamaged, and mold-damaged) for broiler chickens and to correlate then with corn density.

\section{MATERIAL AND METHODS}

Physical analyses of corn were carried out on grains collected in the state of Goiás, Brazil, during the 2007/2008 harvest. Grains were classified and segregated according to the Brazilian official system (MAPA, 1996) into the following categories: sound, fermented, insect-damaged, and mold-damaged. These fractions were then analyzed by the Weende method to determine dry matter (DM), crude fiber $(C F)$, ether extract (EE), and crude protein (CP) contents. Gross energy (GE) levels were determined using a calorimetry bomb (model C2000 - IKA). Corn bulk density was determined using a densimetric table (Zaccaria MDZ-120, São Paulo, Brazil), which stratifies grains by their density or specific weight and was expressed in mass per hectoliter $(\mathrm{kg} / \mathrm{HL})$.

Based on this classification, a reference corn type was created, consisting of $95.5 \%$ sound, $0.8 \%$ fermented, $0.05 \%$ insect-damaged, and 3.3\% molddamaged grains. A reference diet (T1) was formulated with the reference corn to contain 3,000 kcal apparent metabolizable energy (AME), 19\% CP, 1.0\% digestible lysine, $0.78 \%$ methionine + cysteine, and to supply the requirements of the other nutrients, according to bird age (Rostagno, 2011). The other treatment diets were based on T1, as follows: T2- $60 \% \mathrm{~T} 1+40 \%$ corn using sound grains only, T3- $60 \% \mathrm{~T} 1+40 \%$ only fermented grains, T4- $60 \%$ T1 $+40 \%$ only insect-damaged grains, T5- $60 \%$ T1 $+40 \%$ mold-damaged grains, and $\mathrm{T} 6=60 \% \mathrm{~T} 1+40 \%$ corn used in the reference diet. The diets were offered ad libitum as mash.

One hundred and eighty 22-day-old male Cobb 500 broilers were used. Birds were weighed at the beginning of the experiment, and presented 1080 $g$ average body weight. The experiment was carried out in a metabolism room with a digitally controlled environment at the experimental facilities of NUTRON, Mogi-Mirim, SP, Brazil. During the experimental period, $23.5^{\circ} \mathrm{C}$ average temperature was recorded $\left(22.2^{\circ} \mathrm{C}\right.$ minimum and $25.3^{\circ} \mathrm{C}$ maximum). Cages were equipped with excreta collection trays, individual trough feeders, and nipple drinkers.

Birds were distributed according to a completely randomized experimental consisting of six treatments, with six replicates of five birds each. Birds for each replicate were housed in the metabolic cages for seven days, with three days for adaptation and four days for data collection (Cortés et al., 2009). The beginning and the end of period of excreta collection was determined by the addition of ferric oxide (1\%) to the diets as fecal marker. Excreta were collected twice daily in the morning and afternoon.

The collected excreta were stored in a freezer at $-5^{\circ} \mathrm{C}$ until the end of the experiment. Feed offer and feed residues were weighed and recorded per cage. At the end of the experiment, all excreta and feed samples were thawed, weighed, and homogenized. They were then pre-dried in a forced-ventilation oven at $55^{\circ} \mathrm{C}$ for 72 hours and weighed. Samples were then dried in the same oven at $105^{\circ} \mathrm{C}$ until constant weight, ground in a hammer mill fitted with $0.5-\mathrm{mm}$ mesh. Dry matter $(D M)$, gross energy (GE), ether extract (EE), and crude protein $(\mathrm{CP})$ contents were determined according to Silva \& Queiros (2002).

Apparent metabolizable energy values corrected for nitrogen balance (AMEn) were determined according to Sakomura \& Rostagno (2007). Metabolizable energy (ME) values of the corn fractions were calculated using the formula proposed by Matterson et al. (1965). Metabolizability coefficients of dry matter (MCDM), crude protein (MCCP), ether extract (MCEE), and gross energy (MCCE) of the reference corn and its fractions were also calculated.

Regressions of corn density on metabolizable energy were calculated. The effects of corn fractions on the traits measured were evaluated using analysis of variance and (linear and quadratic) regression analysis using SAS ${ }^{\circledR}$. Means were compared by the test of Tukey at 5\% significance level. Pearson's correlations between corn density and metabolizability coefficients were calculated.

\section{RESULTS AND DISCUSSION}

The sound corn (T2) and the reference corn (T6) presented similar DM, CP, CF, EE, and GE (Table 1) contents when compared to the Brazilian Tables (Rostagno, 2011). The insect-damaged and mold- 
damaged grains had higher CP levels compared with sound corn (17.8 and $26.0 \%$, respectively). Nevertheless, the density of these fractions were 23.2 and $18.6 \%$ lower, respectively. Dale \& Jackson (1994) and Silva et al. (2008) attributed the fact that low density corns have higher CP level to the low starch content of grains with low specific weights, thereby increasing the concentration of the other nutrients. According to Lilburn and Dale (1989), this high CP level, however, is not reflected in higher amino acid levels, such as methionine, cysteine and lysine, and therefore, the authors suggest that amino acid levels in low-density corn grains should not be corrected due to the increase in CP level. Dale (1995) observed that corn contaminated with fungi have substantially higher protein levels than non-contaminated corn and verified that lower density fractions showed higher contamination and higher powder and fine particle concentrations. The fermented grains presented slightly lower CP than sound grains and $10 \%$ lower density. Differences among corn fractions are expected due to climate, storage, and processing, which interfere in the chemical composition of the feed (Albino et al., 1992). As the corn fractions were manually separated to characterize experimental treatments in the present experiment, variations in their physical traits also were expect.

Chemical composition values, on dry matter basis, presented the following differences among corn fractions: $23 \%$ for CP (8.86 to $11.54 \%), 21 \%$ for CF (1.97 to $2.49 \%$ ), and $9.2 \%$ for EE (4.24 to $4.67 \%$ ). A $23 \%$ density difference (675 to $879 \mathrm{~g} / \mathrm{L}$ ) was also detected. However, gross energy (GE) values were similar among the corn fractions analyzed ( $2 \%$ variation).
Density is also used as a criterion in the evaluation of corn nutritional quality. Leeson \& Summers (1997) stated that in the USA, density is the main measure of corn quality evaluation, together with the determination of damaged and broken grains and foreign material levels. Baidoo et al. (1991) found that corn energy values linearly increased with grain density; however, high reductions in grain densities resulted in small reductions in GE. This is in agreement with the results of the present study, where a small GE reduction (2\%) between the highest density (sound corn) and the lowest density grains (insect-damaged corn) was observed. In the study of Baidoo et al. (1991), a 20\% decrease in corn density was correlated with a mere $4.3 \%$ reduction in AME. Lesson \& Summers (1976) had previously verified that when the density of corn samples harvested in a same year varied in approximately $40 \%$, their metabolizable energy, determined in adult cockerels, varied only $12 \%$.

Silva et al. (2008) found that low-density corns presented lower percentage of insect-damaged grains, but higher percentage of hollow, broken and mold-damaged grains than high-density corns. In the present experiment, insect-damaged grains present the lowest density among the evaluated grain types. Changes in the nutritional values of grains are related to the preferences of insects for the germ (Lopes et al., 1988). On the other hand, Stringhini et al. (2000) evaluated the performance of 1 - to 28-day-old broilers fed diets containing insect-damaged corn (0 to 40\%) and did not find any significant differences in weight gain, feed conversion, or liver, pancreas, and bursa weights relative to body weight.

Table 1 - Chemical composition, energy and density of different corn fractions

\begin{tabular}{|c|c|c|c|c|c|c|}
\hline Fraction of corn & $\begin{array}{c}\text { T2 } \\
\text { Sound }\end{array}$ & $\begin{array}{c}\text { T3 } \\
\text { Fermented }\end{array}$ & $\begin{array}{c}\text { T4 } \\
\text { Insect-damaged }\end{array}$ & $\begin{array}{c}\text { T5 } \\
\text { Mold-damaged }\end{array}$ & $\begin{array}{c}\text { T6 } \\
\text { Reference }\end{array}$ & $\begin{array}{l}\text { Brazilian } \\
\text { Tables* }\end{array}$ \\
\hline \multicolumn{7}{|c|}{ Values expressed on "as-fed" basis } \\
\hline Dry matter. \% & 88.4 & 88.0 & 86.2 & 88.4 & 88.8 & 87.5 \\
\hline Crude Protein. \% & 8.1 & 7.8 & 9.3 & 10.2 & 8.0 & 7.88 \\
\hline Crude fiber. \% & 1.79 & 1.86 & 2.15 & 1.74 & 1.99 & 1.73 \\
\hline Ether extract \% & 3.85 & 4.11 & 3.92 & 3.75 & 4.13 & 3.65 \\
\hline Density g/L & 777 & 697 & 582 & 632 & 736 & - \\
\hline Crude energy. kcal/kg & 3977 & 3981 & 3952 & 3991 & 3978 & 3940 \\
\hline \multicolumn{7}{|c|}{ Values expressed on dry matter basis } \\
\hline Crude Protein. \% & 9.16 & 8.86 & 10.79 & 11.54 & 9.01 & 9.00 \\
\hline Crude fiber. \% & 2.02 & 2.11 & 2.49 & 1.97 & 2.24 & 1.98 \\
\hline Ether extract \% & 4.36 & 4.67 & 4.55 & 4.24 & 4.65 & 4.17 \\
\hline Density g/L & 879 & 792 & 675 & 715 & 829 & \\
\hline Crude energy. kcal/kg & 4499 & 4524 & 4585 & 4515 & 4480 & 4503 \\
\hline
\end{tabular}

*Rostagno (2011) 
When expressed on "as-fed" basis, the AMEn content of the insect-damaged corn was lower than that of the other grains (Table 2), due the $2 \%$ lower water content of this fraction (Table 1). Nevertheless, AMEn levels on DM basis were not different among the corn fractions (data not shown) ( $p>0.05)$. On the other hand, Silva et al. (2008), comparing corns with densities of $805.1,736.6$, and $592.9 \mathrm{~kg} / \mathrm{m}^{3}$, found that ME levels decreased with density. It had been shown that fungi and insect infestation affect corn quality. For instance, Krabbe et al. (1994) found that the level of fungal infection in corn is proportional to feed ME reduction, especially due to reduced EE content. Antunes et al. (2011) observed that insect infestation level influences the chemical composition of the corn grain. Therefore, we hypothesize that the corn used in the present experiment presented better quality than those evaluated in the previously mentioned, including a smaller fraction of insect-damaged grains.

The obtained AMEn values were different from those reported in Brazilian (Rostagno, 2011) and international (NRC, 1994) literature. Rostagno (2011), based on prediction equations, calculated a ME value of $3432 \mathrm{kcal} / \mathrm{kg}$ (on "as-fed" basis) for standard corn. The equation proposed by Rostagno (2011) estimates highest ME losses due to fungi and insect damage in the different corn fractions studied here. On the other hand, Dale \& Jackson (1994) reported that broken grains and foreign material reduce true ME for poultry in 5.6 and $17 \%$, respectively.

No references on AME values of the different corn fractions were found in the literature. Mean AME values reported in other experiments (Albino et al., 1992; Dale \& Jackson, 1994; Silva et al., 2008) were obtained from mixed corn samples, containing different fractions in different proportions, but not for stratified fractions as in the present experiment.

The calculated DM metabolizability of molddamaged corn was lower (Table 2) compared with sound and fermented corn, but similar to that of insectdamaged and reference samples. Insect-damaged and mold-damaged corn also presented significantly lower $(p<0.05)$ coefficients of protein metabolizability compared with the other corn fractions.

Insect-damaged and mold-damaged corn fractions presented higher $\mathrm{CP}$ levels than sound corn (Table 1). The results in the present experiment show that, although the CP content of these fractions was higher, it was not well utilized by the broilers, leading to lower CP metabolizability. This is in agreement with Lilburn and Dale (1989), who verified that the higher protein levels found in the lower density grains did not lead to an increase in essential amino acids levels, such as lysine and methionine.

The coefficients of EE and GE metabolizabilty (Table 2) did not differ among the different corn fractions ( $p>0.05)$. All corn fractions presented high level of energy utilization (above $80 \%$ ), demonstrating the importance of corn for broiler nutrition. However, the corn MGE coefficient (86\%) presented in the Brazilian Tables (Rostagno, 2011) is higher than the values found in the present study.

Table 3 shows the correlations among the measured corn parameters. All correlations were positive and influenced by grain density. Density presented low correlation with AMEn and MGE $(r<0.5)$ and high correlation with MCP $(r=0.83)$, whereas it was intermediately correlated with the other evaluated characteristics. These data are in agreement and with complementary to metabolizability data, which showed that grain protein utilization by broilers was the most sensitive factor to changes in corn density (Table 2).

Intermediate correlations were determined between MDM and MEE and MDM and MCP (0.58 and 0.73, respectively); however, the correlation between MDM and MGE $(r=0.93)$ was high. The correlation between MCP and MEE was low $(r=0.41)$, but it was high

Table 2 - Density (g/L), AMEn on "as-fed" basis (AF), metabolizability coefficients of dry matter (MDM), crude protein (MCP), ether extract (MEE), gross energy (MGE) of corn fractions fed to 26- to 29-d-old broilers.

\begin{tabular}{|c|c|c|c|c|c|c|}
\hline Treatment & $\begin{array}{c}\text { Density } \\
\mathrm{g} / \mathrm{L}\end{array}$ & AMEn $\mathrm{kcal} / \mathrm{g} \mathrm{NM}$ & $\begin{array}{c}\text { MDM } \\
(\%)\end{array}$ & $\begin{array}{c}\text { MCP } \\
(\%)\end{array}$ & $\begin{array}{c}\text { MEE } \\
(\%)\end{array}$ & $\begin{array}{c}\text { MGE } \\
(\%)\end{array}$ \\
\hline Sound & 777 & $3310 a^{*}$ & $84.39 a$ & $66.8 \mathrm{a}$ & $66.15 \mathrm{a}$ & $83.49 a$ \\
\hline Fermented & 697 & 3266 a & $84.28 \mathrm{a}$ & $62.2 \mathrm{a}$ & $60.69 \mathrm{a}$ & $83.32 \mathrm{a}$ \\
\hline Insect-damaged & 582 & 3122 b & $81.49 a b$ & $51.7 b$ & 50.03 a & 80.87 a \\
\hline Mold-damaged & 632 & $3244 a b$ & 80.37 b & $46.7 b$ & $61.31 \mathrm{a}$ & $80.74 \mathrm{a}$ \\
\hline Control & 736 & 3290 a & $82.98 \mathrm{ab}$ & $62.2 \mathrm{a}$ & 64.09 a & $82.35 \mathrm{a}$ \\
\hline Mean & $677.6 \pm 71.4$ & $3240 \pm 0.10$ & $82.6 \pm 2.5$ & $57.3 \pm 8.2$ & $59.8 \pm 9.7$ & $82.1 \pm 2.3$ \\
\hline CV\% & & 2.32 & 2.39 & 5.46 & 14.19 & 2.64 \\
\hline
\end{tabular}

*Numbers followed by the same letters in the same column are not statistically different ( $p>0.05$ ) by Tukey's test. 
between MEE and MGE ( $r=0.70)$. All correlations of AMEnDM and AMEnMN with other variables were high ( $r>0.75)$, except for MCP, which were low and intermediate (0.48 and 0.52 , respectively).

Table 3 - Correlations between grain density (Den), metabolizability coefficients of dry matter (MDM), crude protein (MCP), ether extract (MEE), gross energy (MGE), AMEn on dry (DM) and as-fed (AF) basis.

\begin{tabular}{lcccccc}
\hline AMEnDM & $\begin{array}{c}\text { Dens } \\
0.47^{*}\end{array}$ & AMEnDM & AMEnAF & MDM & MCP & MEE \\
AMEnAF & 0.65 & 0.95 & & & & \\
MDM & 0.55 & 0.89 & 0.79 & & & \\
MCP & 0.83 & 0.48 & 0.52 & 0.73 & & \\
MEE & 0.53 & 0.77 & 0.82 & 0.58 & 0.41 & \\
MGE & 0.46 & 0.94 & 0.85 & 0.93 & 0.56 & 0.70 \\
\hline
\end{tabular}

${ }^{*}$ All correlations were significant at $p<0.01$

The correlation between density and AMEnDM was low (0.47), in agreement with Lesson et al. (1993) and Lesson \& Summers (1976), who asserted that corn density is not a sound predictor of nutritional value. On the other hand, Silva et al. (2008), testing corns with different densities (805, 737, and $593 \mathrm{~g} / \mathrm{L}$ ), verified significant energy losses at lower densities, estimating that a $26 \%$ reduction in corn density caused a $12 \%$ reduction in AMEn. Nevertheless, that author did not find any significant effects of the inclusion of increasing levels of low-density corn on broiler performance.

All results of the regression of density against metabolizable energy and metabolizability coefficients were low, but significant, and presented a linear behavior (Figures 1 and 2). These effects were also observed by Silva et al. (2008) and Silva et al. (2011); however, these authors did not determine coefficients of metabolizability.

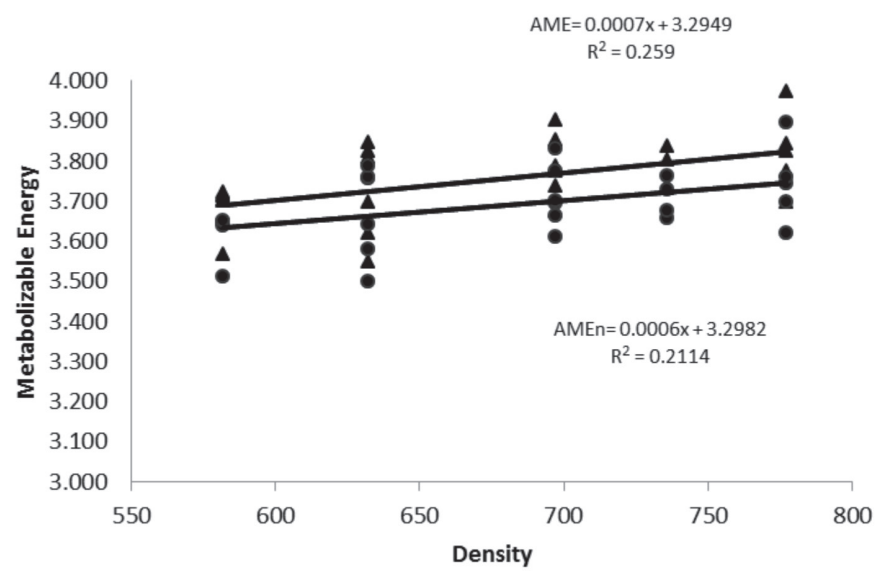

Figure 1- Effect of density on apparent metabolizable energy (AME) corrected for nitrogen (AMEn) in dry matter
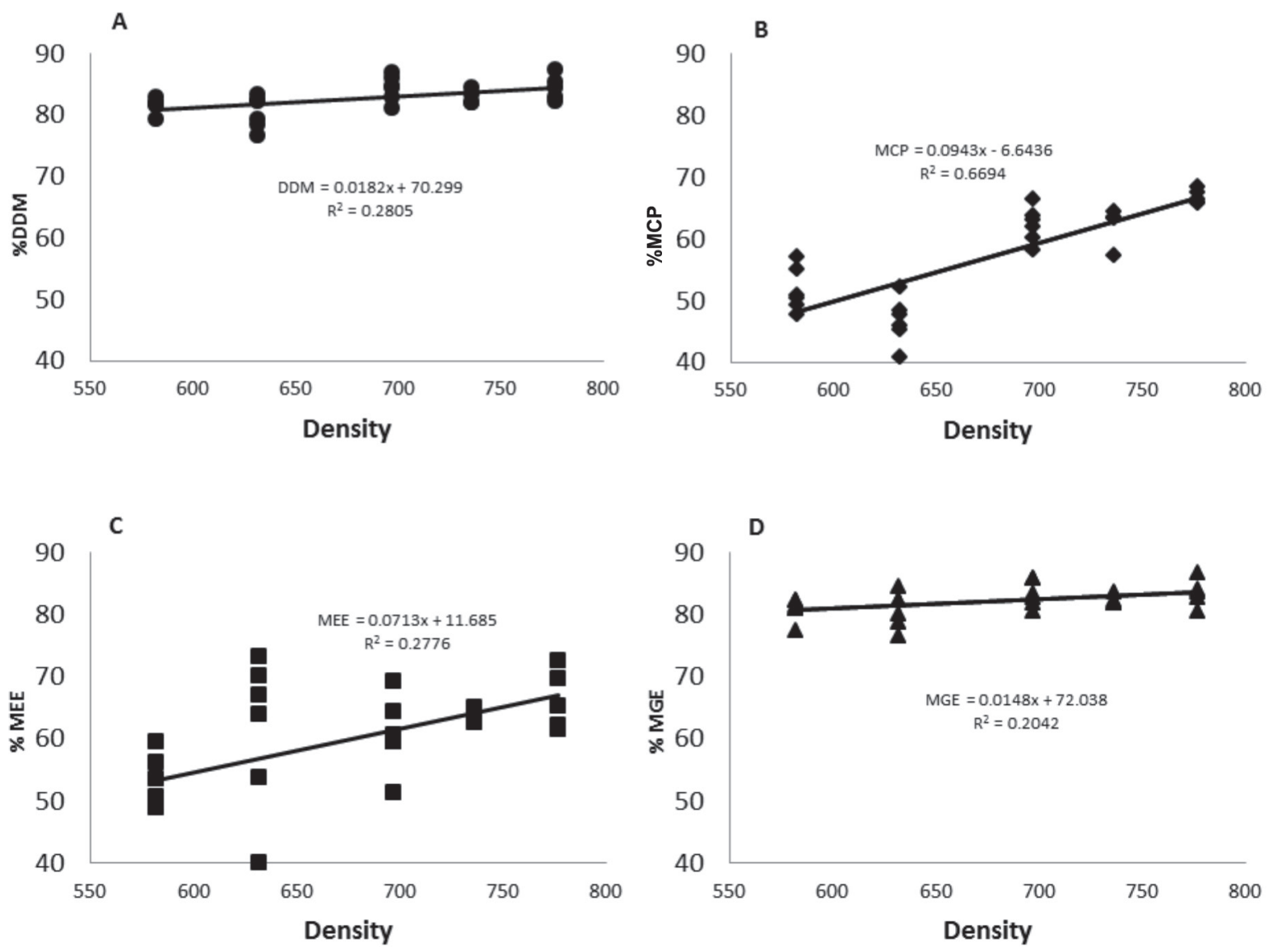

Figure 2. Effect of grain density on metabolizability of dry matter (DDM), crude protein (MCP), ether extract (MEE) and gross energy (MGE) 
Nutritional level changes do not always alter digestive use of nutrients. For instance, Stringhini et al. (2000), evaluating corn quality for broilers, found high protein levels in poor quality corn, such as that contaminated with insects or fungi. However, the diet containing this corn also affected the birds' health status, causing leg and digestive problems. Bartov et al. (1982) found that fat and fat-soluble vitamin levels are reduced as grain contamination with fungi increases. Carvalho et al. (2004 and 2009), despite not detecting changes in the chemical composition and in gross energy levels of corn submitted to different drying temperatures $\left(80\right.$ to $120^{\circ} \mathrm{C}$ ) and storage periods (0 to 180 days), observed reduced AME and amino acid digestibility values as drying temperatures and storage periods increased. In the present study, corn energy and nutrient utilization were not markedly different, which may due to the high quality of the corn samples used. The use of corn harvested in different years or regions may lead to more contrasting results.

\section{FINAL CONSIDERATIONS}

The evaluated corn fractions presented different chemical composition, different protein metabolizability values, and similar AME values. Corn density was not a sound predictor of AME content, but provided a sound prediction of metabolizable protein level.

\section{REFERENCES}

Albino LFT, Rostagno HS, Tafuri ML ,Almeida e Silva M. Determinação dos valores de energia metabolizável aparente e verdadeira de alguns alimentos para aves, usando diferentes métodos. Revista Brasileira de Zootecnia 1992;21:1047-1058.

Antunes LEG, Viebrantz PC, Gottardi R, Dionello RG. Caracteristicas físicoquímicas de grãos de milho atacados por Sitiphilus Zeamais durante o armazenamento. Revista Brasileira de Engenharia Agrícola e Ambiental 2011;51:615-620.

Baidoo SK, Sheres A, Robblee AR. Effect of kernel density on the on the apparent and true metabolizable energy value of corn for chickens. Poultry Science 1991;70:2102-2107.

Bartov I, Paster N, Lisker N. The nutritional value of moldy grains for broiler chicks. Poultry Science 1982;61:2247-2254.

Carvalho DCO, Albino LFT, Rostagno HS, Oliveira JE, Vargas Jr JG, Toledo RS, Costa CHR, Pinheiro SRF, Souza RM. Composição Química e Energética de Amostras de Milho Submetidas a Diferentes Temperaturas de Secagem e Períodos de Armazenamento. Revista Brasileira de Zootecnia 2004;33:358-364.

Carvalho DCO, Albino LFT, Vargas Jr JG, Toledo RS, Oliveira JE, Souza RM. Coeficiente de digestibilidade verdadeira dos aminoácidos e valores de aminoácidos digestíveis do milho submetido a diferentes temperaturas de secagem e períodos de armazenamento. Revista Brasileira de Zootecnia 2009;38:850-856

CONAB - Companhia Nacional de Abastecimento. Conjuntura semanal: milho. Período: 13 a 24/04/2015 [cited 2015 May 4]. Available from: http://www.conab.gov.br/OlalaCMS//uploads/ arquivos/15_04_28_17_52_28_conjuntura_semanal_de_milho de_13_a_24.pdf.

Cortés MEM, Ribeiro AML, Gianfelice MF, Kessler AM, Moraes ML. Study of methodological variations in apparent nutrient metabolismo determination in broiler chickens. Revista Brasileira de Zootecnia 2009;38:1921-1927.

Dale N, Jackson D. True metabolizable energy of corn fractions. Journal of Applied Poultry Research 1994;3:179-183.

Dale N. Ingredient analyses table. Feedstuffs 1995;67:24-31.

Galon L, Tironi SP, Rocha AA, Soares ER, Concenço G, Alberto CM. Influência dos fatores abióticos na produtividade da cultura do milho. Revista Trópica - Ciências Agrárias e Biológicas 2010;4:18-38.

Krabbe EL, Penz Jr AM, Lazzari FA, Reginatto MF. Efeito da umidade e do ácido propiônico sobre as características bromatológicas e microbiológicas de grãos de milho. Conferência Apinco de Ciência e Tecnologia Avícolas; 1994; Santos, São Paulo Brasil. Campinas: Facta/ WPSA; 1994. p.27-28.

Leeson S, Summers JD. Effect of adverse growing conditions on corn maturity and feeding value for poultry. Poultry Science 1976;55:588593.

Leeson S, Summers JD. Commercial poultry nutrition. 2nd ed. Guelph: University Books; 1997

Leeson S, Yersen A, Volker L. Nutritive value of the 1992 corn crop. Journal of Applied Poultry Research 1993;2:208-213.

Lilburn MS, Dale N. Characterization of two samples of corn may vary in bushel weights. Poultry Science 1989;68:857-860.

Lopes DC, Fontes RA, Donzele JL, Alvarenga JC. Perda de peso e mudanças na composição química do milho (Zea mays,L.) devido ao carunchamento. Revista Brasileira de Zootecnia 1988;17:367-371.

Lopes DC, Alvarenga JC, Donzele JL, Fontes, RdeA, Vieira AA. Efeito do nível de carunchamento do milho sobre o desempenho de suínos em crescimento/terminação. Revista Brasileira de Zootecnia 1990;19:147151.

MAPA - Ministério da Agricultura, Pecuária e Abastecimento. Portaria $n^{\circ}$ 845, de 8 de novembro de 1976.

MAPA - Ministério da Agricultura, Pecuária e Abastecimento. Portaria $n^{\circ}$ 11, de 12 de abril de 1996.

MAPA - Ministério da Agricultura, Pecuária e Abastecimento. Instrução Normativa $n^{\circ}$ 60, de 23 de dezembro de 2011 [cited 2015 May 4]. Available from: http://sistemasweb.agricultura.gov.br/sislegis/ action/detalhaAto.do? method=visualizarAtoPortalMapa\&cha ve $=1739574738$.

Matterson LD, Potter LM, Stutz NW Singsen, EP. The metabolizable energy of feed ingredients for chickens. Agricultural Experiment Station Research Report 1965;7:3-22

NRC- National Research Council. Nutrient requirements of poultry. 9th ed. Washington: National Academy Press; 1994. 155p.

Rostagno HS, Tabelas Brasileiras para aves e suínos. Composição de Alimentos e Exigências Nutricionais. $3^{\mathrm{a}}$ ed. Viçosa: Universidade Federal de Viçosa; 2011

Sakomura N, Rostagno HS. Métodos de pesquisa em nutrição de monogástricos. Jaboticabal: FUNEP; 2007.

Silva DJ, Queiros AC. Análises de alimentos: métodos químicos e biológicos. Viçosa Universidade Federal de Viçosa; 2002

Silva CS, Couto HP, Ferreira RA, Fonseca JB, Gomes, AVC, Soares RTRB. Valores nutricionais de milhos de diferentes qualidades para frangos de corte. Revista Brasileira de Zootecnia 2008;37:883-889.

Silva CS, Menten JFM, Traldi AB, Santarosa J, Pereira PWZ. Avaliação de milhos de diferentes densidades para frangos de corte. Revista Brasileira de Zootecnia 2011;40:1554-1561.

Stringhini JH, Mogyca NS, Andrade MA, Orsine GF, Café MB, Borges, AS. Efeito da qualidade do milho no desempenho de frangos de corte. Revista Brasileira de Zootecnia 2000;29:191-198. 